\title{
Current status on lithium disilicate and zirconia: a narrative review
}

\author{
Fernando Zarone(D, Maria Irene Di Mauro*, Pietro Ausiello, Gennaro Ruggiero and Roberto Sorrentino
}

\begin{abstract}
Background: The introduction of the new generation of particle-filled and high strength ceramics, hybrid composites and technopolymers in the last decade has offered an extensive palette of dental materials broadening the clinical indications in fixed prosthodontics, in the light of minimally invasive dentistry dictates. Moreover, last years have seen a dramatic increase in the patients' demand for non-metallic materials, sometimes induced by metal-phobia or alleged allergies. Therefore, the attention of scientific research has been progressively focusing on such materials, particularly on lithium disilicate and zirconia, in order to shed light on properties, indications and limitations of the new protagonists of the prosthetic scene.

Methods: This article is aimed at providing a narrative review regarding the state-of-the-art in the field of these popular ceramic materials, as to their physical-chemical, mechanical and optical properties, as well as to the proper dental applications, by means of scientific literature analysis and with reference to the authors' clinical experience.

Results: A huge amount of data, sometimes conflicting, is available today. Both in vitro and in vivo studies pointed out the outstanding peculiarities of lithium disilicate and zirconia: unparalleled optical and esthetic properties, together with high biocompatibility, high mechanical resistance, reduced thickness and favorable wear behavior have been increasingly orientating the clinicians' choice toward such ceramics.

Conclusions: The noticeable properties and versatility make lithium disilicate and zirconia materials of choice for modern prosthetic dentistry, requiring high esthetic and mechanical performances combined with a minimal invasive approach, so that the utilization of such metal-free ceramics has become more and more widespread over time.
\end{abstract}

Keywords: Lithium disilicate, Zirconia, ZLS, Ceramic, Minimally invasive, E.max, MDP, Aging, Translucent cubic zirconia

\section{Background}

At "The Digital Dentistry Society II Consensus Conference on Digital Technologies - Marrakech 2018" the main topics of digital interest were thoroughly discussed, in order to draw clinical recommendations based on scientific evidence and, when missing, on the clinical experience shared by the scientific community. The present narrative review is focused on the technical and clinical profile of the two most popular metal-free materials, lithium disilicate and zirconia, in order to briefly

\footnotetext{
* Correspondence: mariadimauro94@gmail.com

This Manuscript is considered to be as part of - "The Digital Dentistry Society Il Consensus Conference on Digital Technologies - Marrakech" thematic series.

Department of Neurosciences, Reproductive and Odontostomatological

Sciences, University "Federico II" of Naples, Viale Pansini, 5 -, 80131 Naples, Italy
}

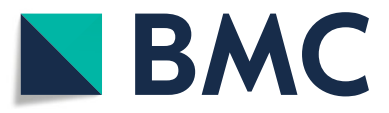

(๑) The Author(s). 2019 Open Access This article is distributed under the terms of the Creative Commons Attribution 4.0 International License (http://creativecommons.org/licenses/by/4.0/), which permits unrestricted use, distribution, and reproduction in any medium, provided you give appropriate credit to the original author(s) and the source, provide a link to the Creative Commons license, and indicate if changes were made. The Creative Commons Public Domain Dedication waiver (http://creativecommons.org/publicdomain/zero/1.0/) applies to the data made available in this article, unless otherwise stated. shed light on their different indications, advantages and shortcomings.

\section{Methods}

An extensive research has been carried out in the literature available on the subject, worldwide, limiting itself exclusively to articles in english, available on the main search engines (Pubmed, Embase, Scopus) and published in the most important indexed journals of the Materials and Dental sector, with and without impact factor. The results highlighted in this narrative review were extrapolated from this literature search, with reference to the authors' clinical experience. 


\section{Results}

Lithium disilicate

Physico-chemical features, optical and mechanical properties

Lithium disilicate $\left(\mathrm{LS}_{2}\right)$ is classified as a glass-ceramic, in the class of particle-filled glass materials. Introduced on the market in the 90s with the commercial formulation named "IPS Empress 2" (Ivoclar Vivadent, Schaan, Liechtenstein), it was composed of $65 \mathrm{vol} \%$ lithium disilicate, small needle-shaped crystals $(3-6 \mu \mathrm{m} \times 0.8 \mu \mathrm{m})$ embedded in a glass matrix, with a 1 vol\% porosity [1-3], showing valuable mechanical characteristics (flexural strength: $350 \mathrm{MPa}$; fracture toughness (KIC): $3.3 \mathrm{MPa} \sqrt{\mathrm{m}}$; heat extrusion temperature: $920^{\circ} \mathrm{C}$; thermal expansion coefficient (CTE): $\left.10.6+0.25 \mathrm{ppm} /{ }^{\circ} \mathrm{C}\right)$. At first, this material was made commercially available as ingots, to be utilized according to the "heat-pressing" fabrication procedure, similar to the classic "lost wax" technique for metal-alloy casts, aimed at producing cores, hot pressed into a mold. In order to get an appealing reproduction of the optical characteristics of natural teeth, the cores are lately veneered with a very translucent fluorapatite ceramic, containing $19-23 \%$ of fluorapatite crystals $\left(\mathrm{Ca}_{5}\left(\mathrm{PO}_{4}\right)_{3} \mathrm{~F}\right)$ embedded in a glassy matrix [4].

Thanks to an optimization of the processing parameters, allowing the formation of smaller and more uniformly distributed crystals, in 2005 a new formulation of $\mathrm{LS}_{2}$ was marketed as "IPS e.max Press" (Ivoclar Vivadent), exhibiting improved mechanical properties and optical features (flexural strength: 370-460 MPa; fracture toughness (KIC): $2.8-3.5 \mathrm{MPa} \sqrt{\mathrm{m}}$ ), much higher than the older glass-ceramics. The high mechanical performance of this material is due, on one side, to a layered, tightly interlocked distribution of the elongated disilicate crystals, hindering crack propagation across the planes and, on the other side, to a mismatch between the thermal expansion coefficients of $\mathrm{LS}_{2}$ crystals and the glassy matrix, so that the latter induces a tangential, compressive stress around the crystals [2]. Besides the production of ceramic cores for bilayered crowns, the increase of strength and toughness of IPS e.max Press has allowed to extend its clinical indication to monolithic restorations, without veneering ceramic, anatomically shaped, colored by surface stains and characterized by a higher fatigue resistance than the bilayered ones.

Besides the heat-pressed technique, the widespread, increasing implementation of computer-aided design/computer-aided manufacturing (CAD-CAM) technologies has led to the introduction of ceramic blocks aimed at the production of restorations by milling devices (IPS e.max CAD), also suitable for chairside production of restorations. Partially, pre-crystallized blocks are manufactured in a "blue state", containing $40 \%$ of metasilicates $\left(\mathrm{Li}_{2} \mathrm{SiO}_{3}\right)$ in addition to lithium disilicate crystal nuclei
$\left(\mathrm{Li}_{2} \mathrm{Si}_{2} \mathrm{O}_{5}\right)$. Such blocks are characterized by moderate flexural strength of $\sim 130 \mathrm{MPa}$, resulting in higher cutting efficiency, easier and faster workability and lower wear of the milling tools $[2,3,5]$. The milling procedure is performed in this pre-crystallized state and, after its completion, it is followed by a heating cycle $\left(840^{\circ}-850{ }^{\circ} \mathrm{C}\right.$ for $10 \mathrm{~min}$ ) that turns metasilicate crystals into lithium disilicate $(\sim 70 \%)$, increasing the flexural strength up to values of $262 \pm 88 \mathrm{MPa}$, together with a fracture toughness of $2.5 \mathrm{MPa} \cdot \mathrm{m}^{1 / 2}$. The blocks are available in different colors, obtained by dispersing staining ions in the glassy matrix [6] and in different degrees of translucency, on the basis of the size and distribution of the crystals in the glassy matrix [4]. The variability of flexural strength of lithium disilicate among heat-pressed and CAD-CAM blocks with different translucency is still under debate [7, 8]. Particularly, the flexural strength of IPS e.max Press and IPS e.max CAD was reported to be similar and the manufacturing process did not seem to affect the mechanical characteristics of lithium disilicate ceramics; moreover, the flexural strength was significantly influenced by translucency only for CAD-processed materials [7].

In vitro fully anatomical e.max CAD crowns have been shown to exhibit fracture resistance that is suitable for posterior, monolithic restorations [9] and to be more resistant to fatigue in cyclic loading than veneered zirconia, that is more prone to chipping [10]. For the high interest generated by its clinical versatility, further developments are expected on this material, being it influenced by different production processes, like thermal gradients, times and rates, that affect its microstructure and mechanical properties. It has been shown, for instance, that extending temperature range $\left(750-840{ }^{\circ} \mathrm{C}\right.$, compared to the standard $820-840^{\circ} \mathrm{C}$ ) or prolonging holding time $\left(14 \mathrm{~min}\right.$ vs $7 \mathrm{~min}$ at $8400^{\circ} \mathrm{C}$ ) increase elastic modulus and hardness properties, without affecting flexural strength and fracture toughness [11]. Moreover, new technologies, as spark plasma sintering, can induce a refinement and a densification of the nano-crystalline microstructure, increasing lithium disilicate and metasilicate phases and reducing lithium orthophosphate and cristobalite/quartz phases [12, 13].

As regards mechanical resistance, it has been clearly demonstrated that, in vitro, veneered $\mathrm{LS}_{2}$ crowns exhibit significantly lower fracture load values (1431.1 \pm 404.3 $\mathrm{N})$ compared to monolithic ones $(2665.4 \pm 759.2 \mathrm{~N})$, the main failure mechanism being bulk fracture initiating from the occlusal surface [14]. To date, there is strong evidence from in vitro studies that, differently from bilayered restorations, monolithic ones show fracture strength and fatigue resistance suitable for use in the posterior areas, both in tooth- and implant-supported single crowns (SC) and 3-unit fixed dental prostheses (FDPs) [15-22]. 
Monolithic $\mathrm{LS}_{2}$, as well as Zirconia reinforced-Lithium Silicate ceramics (ZLS), offers higher fracture resistance than bilayered, hand-veneered zirconia [20], while a recent in vitro research has shown that load-to-fracture values of monolithic zirconia are higher than those of $\mathrm{LS}_{2}$; the latter, in turn, are higher than those of ZLS [23].

It has to be pointed out, however, that, particularly as regards $\mathrm{LS}_{2}$, fatigue resistance is strongly influenced by many experimental variables, like amount of cyclic loading, abutment and antagonist design and material, thermocycling parameters and test environment; for this reason, the heterogeneity and lack of standardization in research designs, tested materials and experimental conditions make a comparison of data not easily feasible [24].

\section{Abrasiveness and wear}

As to wear and abrasiveness, $\mathrm{LS}_{2}$ shows quite favourable properties, that are highly depending on the surface characteristics of the restoration. When accurately polished at its surface, the material exhibits convenient tribological behaviour in vitro, in terms of friction and wear of restorations, being its abrasiveness quite close to enamel, although more aggressive when compared to type III gold [25] or to polished monolithic zirconia in in vitro simulations [26-28]. Such favourable wear behaviour and durability have been also confirmed by some in vivo evidence [15].

On the other hand, it has been reported that grinding, glaze coating and fluorapatite ceramic veneering can increase wear, both of the antagonist teeth and of the restoration itself; at the same time, surface roughness can also be increased, besides a reduction of gloss, in the presence of basic $\mathrm{pH}$ environment and after toothbrushing with abrasive toothpaste [29-33]. For these reasons, when it is not crucially needed for esthetic reasons, glazing of monolithic restorations should be avoided on the occlusal surfaces in posterior sites and only limited to the esthetically relevant zones; moreover, careful polishing procedures should always follow any occlusal grinding or esthetic refinement of disilicate restorations, although in vitro evidences at scanning electron microscope (SEM) have shown that $\mathrm{LS}_{2}$ is one of the most critical materials to adjust intraorally, due to significant chip accumulation in the diamond burs, requiring higher machining forces and energy, with likely onset of intergranular and transgranular fractures, besides risks of thermal damage to tissues and restorations [32].

\section{Biocompatibility}

One of the strongest points of $\mathrm{LS}_{2}$ is the excellent quality of soft tissue response. In vitro, this material exhibits high levels of biocompatibility, not only due to low plaque retention, but also to adhesion and proliferation of human epithelial cells [34] and human gingival fibroblasts [35], particularly when its surface is polished. In vivo, in the presence of $\mathrm{LS}_{2}$ restorations no inflammatory reactions were detected, analyzing the concentration of inflammation indicators in the gingival crevicular fluid; the same results were found with zirconia restorations [36]. Such favourable tissue responses have also been confirmed by tissue culture data [34]. In clinical experience, $\mathrm{LS}_{2}$ restorations are likely to yield very natural and sound aspect of soft tissues when in contact with marginal gingiva or peri-implant mucosa, in the presence of subgingival margins.

\section{Surface treatment and cementation}

In addition to excellent biocompatibility and high mechanical properties, $\mathrm{LS}_{2}$ exhibits very good esthetic features, especially as regards translucency, that is about $30 \%$ higher than conventional zirconia [37]. Moreover, for the presence of silica, $\mathrm{LS}_{2}$ is an acid-sensitive ceramics, so that high strength of adhesion to the substrate is expected, due to both micromechanical and chemical bonding mechanisms. Micromechanical interlocking between ceramics and resin cement at the intaglio surface is based on the creation of surface microirregularities, pits and roughness by means of acid etching and/ or physical treatments like alumina particles sandblasting or diamond bur grinding. For the glass-ceramic class, to date hydrofluoric acid (HF) etching is the bestestablished procedure, to be performed according to validated protocols taking into account both acid concentration and etching time. For $\mathrm{LS}_{2}, 20 \mathrm{~s}$ HF etching (at 5\% concentration) is suggested, that is a shorter time than requested for feldspathic and leucite-based ceramics (generally $60 \mathrm{~s}$ ). Higher HF concentrations (9-10\%) and longer etching times have been shown to be too aggressive and can introduce relevant damages, not only to the surface but also to the internal microstructure of the material, negatively influencing mechanical performance (reduction of flexure strength), adhesion potential and long-term success of ceramic restorations, particularly when thickness is low [38-41]. Another system to create surface microirregularities is sandblasting $\mathrm{LS}_{2}$ with aluminum oxide particles. Nevertheless, it has been shown that this procedure, as well as laser etching, can determine excessive loss of material, with surface modifications that are less uniformly distributed than after HF etching and that can significantly reduce flexural strength [42, 43]. In addition to micromechanical interlocking, as for all silicabased materials, adhesive bonding of $\mathrm{LS}_{2}$ is efficiently increased by silane, ensuring a chemical interaction between the resin-based agent and the ceramics, obtained forming strong siloxane linkages [44-50].

Recently, it has been shown that the use of silane combined to a phosphate functional monomer, the 10Methacryloyloxydecyl-Dihydrogen-Phosphate (10-MDP), 
creating an acidic environment further improves the bond strength of resin-based luting cement to lithium disilicate ceramics [51].

\section{Clinical indications and performances}

As regards clinical indications of $\mathrm{LS}_{2}$, it has to be pointed out that this is one of the most versatile metalfree materials for its high esthetic potential, good mechanical properties and favourable bonding strength to dental tissues, thanks to its silica content. Lithium disilicate ceramics can be utilized both for tooth- and implant-supported restorations, ranging from SCs to FDPs, from anterior veneers to posterior inlays, onlays and overlays $[4,7]$.

To date, due to its relatively recent market introduction, there is still a lack of data about long-term outcomes of $\mathrm{LS}_{2}$ restorations, particularly as regards CAD-CAM production. Prospective, medium-term studies reported good cumulative survival rates, both for tooth-supported crowns (94.8\% after 8 years [52]) and implant-supported crowns, made by CAD-CAM procedure following conventional impression (100\% after 5 years [53]). A recent prospective study on implant-supported, single-unit monolithic restorations made of $\mathrm{LS}_{2}$ in a complete digital workflow has demonstrated survival rates of $100 \%$, without any technical or biological complications, after 2 years of service [54]. Similarly, retrospective studies have shown that $\mathrm{LS}_{2}$ can yield satisfactory clinical performance with favourable survival rates and low incidence of mechanical failures, like debonding, fractures and chipping [15, 55-58].

As regards chairside procedures, monolithic $\mathrm{LS}_{2}$ crowns revealed a survival rate of $83.5 \%$ after 10 years of follow-up; the main complications were loss of retention, secondary caries and hypersensitivity [59].

In the last decade, $\mathrm{LS}_{2}$ has been proposed for producing full-contoured, monolithic SCs to be bonded to CAD-CAM zirconia full-arch frameworks supported by implants. In a mid-term study, such a restorative solution exhibited $100 \%$ survival rate, after 5 years of followup [60]. Recently, an in vitro study has suggested that $\mathrm{LS}_{2}$ crowns supported by ceramic-reinforced polyether ether ketone (PEEK) implant abutments may be an alternative to zirconia abutments with a titanium base for single-implant restorations in the anterior region [61].

Thanks to the high reliability of resin bond to glassceramics, $\mathrm{LS}_{2}$ clinical indications also include adhesively retained, tooth-supported restorations. In the anterior sites, in the authors' and in other clinicians' clinical experience, laminate veneers made of bilayered, handveneered $\mathrm{LS}_{2}$ are a likely choice, particularly when clinical performance and high esthetic results are expected [62]. Clinical and in vitro studies demonstrated that, in the presence of long teeth, margins positioned beyond the cemento-enamel junction (CEJ), large areas of exposed dentin or flexural tensile stresses due to high functional loads, laminate veneers are exposed to higher failure risks, being maximum enamel preservation and veneer mechanical resistance paramount success factors $[63,64]$. Due to its mechanical properties, lithium disilicate can be considered a viable option to fabricate ceramic veneers in the presence of unfavorable biomechanical conditions; in fact, it was reported that more rigid ceramic materials exert a kind of shield effect onto underlying tooth structures, strengthening the restorative complex [65].

Since their introduction in 1991, all-ceramic, resinbonded fixed dental prostheses (RBFDPs) have been increasingly utilized as minimally invasive restorations aimed at replacing one missing tooth in the anterior arch [66]. Although recording a high rate of early (1-year), unilateral retainer fractures in conventional, two retainers all-ceramic adhesive bridges, the authors noticed that the fractured, unilaterally supported restorations stayed in situ for 5 to 10 years [67-69]; for that reason, since 1997 cantilevered all-ceramic RBFDPs were proposed as a new conservative treatment modality for replacement of single anterior missing teeth, with minimal tooth preparation on the lingual side, just aimed at achieving a correct positioning during cementation [70]. Different materials have been proposed over the years, mainly, for their high strength, glass-infiltrated alumina ceramics [71] and densely sintered, bilayered zirconia, treated with a combination of moderate pressure air-abrasion and MDP, with promising medium-term outcomes [72-75]. Thanks to its advantageous optical properties and to its HF etching/silane bonding option, $\mathrm{LS}_{2}$ has also been proposed as an alternative material for such cantilevered restorations, showing comparably promising clinical results [76-78]. In a systematic review, cantilevered RBFDPs showed a lower failure rate than conventional, two-retainer, "Maryland bridge-style" ones, in which higher biomechanical stress arises for the different directions of forces acting on the adjacent supporting teeth during anterior guidance in protrusive and lateral mandibular movements [79]. In another recent review, an estimated 91.2\% survival rate at 5 years was reported for all-ceramic RBFDPs, exhibiting higher debonding rate with zirconia resin-bonded restorations than with glass-ceramic ones; conversely a higher fracture rate was reported with glass-ceramics [80], even though higher level of evidence will be necessary to draw final long-term evaluations of all-ceramic RBFDPs clinical performances. RBFDPs are a suitable prosthetic solution as an alternative to implant-supported SCs, in the presence of anatomical impairment requiring costly and invasive surgical procedures, financial problems, young age of patients with congenitally or post-traumatically missing incisors; in any case, to limit the risks of mechanical failure or debonding, after an extensive esthetic, occlusal 
and technical evaluation of the case, a very careful treatment planning has to be defined prior to proceed with the operative phases.

In the posterior sites, $\mathrm{LS}_{2}$ can be successfully employed for resin-bonded single restorations, like inlays, onlays, non-retentive partial crowns and full coverage table-tops, in the monolithic form. The material offers undisputable advantages, like high fracture resistance, showed by high load-at-fracture values in table-tops/occlusal veneers, allowing reduced thickness of the restorations (1-1.5 $\mathrm{mm}$ ), low wear and abrasive potential, adhesive bonding strength and high biocompatibility, properties that are very favourable when teeth are severely abraded or a heavy occlusal correction is needed (like in lateral postorthodontic open bite) [10, 81-85]. These restorative solutions have shown favourable clinical outcomes in the most recent literature, even though with limited follow-up $[86$, 87]. A recent 3-years randomized, controlled prospective trial has shown that $\mathrm{LS}_{2}$ partial crowns can be used as successful restorative solutions for endodontically treated posterior teeth, with no significant differences between premolar or molars and with or without the use of fiber posts [88].

The utilization of $\mathrm{LS}_{2}$ for FDPs is a controversial topic: literature data is quite scant and not homogeneous, with a high variability of reported survival and success rates, ranging from rather poor clinical results [89-92] to acceptable long-term serviceability both in anterior and posterior sites, similar to metal-ceramics [93]. In the opinion of the authors, from a strictly clinical point of view, taking into account the cost/benefit ratio in terms of esthetic needs and structural resistance, the material of choice for 3- or 4-unit FDPs is still zirconia, in all of its different typologies.

\section{Marginal accuracy and internal fit}

Several studies evaluated the adaptation of lithium disilicate restorations, fabricated in both conventional and digital workflow. According to the most recent literature, there is no significant difference in terms of marginal accuracy between conventional and full-digital procedures for the fabrication of monolithic lithium disilicate crowns [94-96]. Moreover, some authors reported that hotpressed $\mathrm{LS}_{2}$ crowns made from conventional impressions with polyvinylsiloxanes exhibit better fit than CAD-CAM digitally produced ones [97].

Furthermore, centralized milling production has been reported to result in better fit compared to chairside system; in the same study, occlusal internal adaptation was better in the conventionally manufactured crowns than in the digitally fabricated ones [95]. Conversely, other studies reported that marginal and internal fit of $\mathrm{LS}_{2}$ crowns were more accurate when using digital impression technique; in any case, whatever the workflow used, the adaptation was shown to be within clinical acceptability range [98-101].

To date, drawing univocal conclusions about adaptation accuracy of lithium disilicate restorations is not easy, due to the high number of variables involved in the final prosthetic fit, like digital impression system and technique, used material and fabrication procedure, so there is still a noticeable amount of controversial debate $[3,102]$. As regards fabrication techniques, hot-pressed lithium disilicate is reported to offer better internal fit and mechanical performances compared to CAD-CAM pre-crystallized blocks, even if, also about this topic, further data will be necessary to definitely shed light on these aspects, due to the constant evolution and increasing quality of milling procedures and devices [103-108].

\section{Zirconia reinforced-Lithium silicate ceramics (ZLS)}

In the last years, the continuous research and progress in prosthetic material field for dental CAD-CAM applications has led to the introduction on the market of promising materials, the ZLS, thanks to an alternative strategy to enhance translucency: a glassy matrix, containing a homogeneous crystalline structure made of lithium silicate crystals, is reinforced with tetragonal zirconia fillers (about $10 \%$ by weight) allowing higher strength values than $\mathrm{LS}_{2}$ [109]. The higher mean translucency, together with proper biaxial flexural strength values, make such material a proper choice for minimally invasive, single tooth esthetic restorations, like inlays, onlays, partial crowns, veneers, anterior and posterior crowns, both tooth- and implantsupported [109, 110], also fulfilling the "no-prep, tabletop" strategy [85]. The restorations show higher translucency and ease of intraoral polishing than both feldspathic and disilicate blocks, but, at the same time, exhibit high brittleness [110-112]. In case of a dark substrate, moreover, it has to be considered that the high translucency of the material requires adequate thickness $(1.5-2.0 \mathrm{~mm})$ in order to get a proper chromatic masking [113].

To date, as regards mechanical properties and clinical performances of ZLS, data are still limited, often controversial and short-term; these highly promising ceramics need further studies, both in vitro and in vivo, in order to precisely define physical-mechanical properties, clinical indications, limits and long-term performance of such restorations [114-117].

\section{Zirconia}

\section{Physico-chemical features}

In the ceramic classification, zirconia $\left(\mathrm{ZrO}_{2}\right)$ is a heterogenous, highly-resistant, polycrystalline ceramic, characterized by favourable mechanical properties (toughness: 5-10 MPa $\sqrt{\mathrm{m}}$, flexural strength: 500-1200 MPa, Young's modulus: $210 \mathrm{GPa}$ ) and good optical characteristics [118-121]; however, differently from 
glass-ceramics, it is not susceptible to conventional acid etching techniques and, consequently, does not take advantage of conventional adhesive bonding procedures [122].

Both in vitro and in vivo, it shows excellent biocompatibility, lower plaque retention than titanium and good radiopacity; moreover, it is not soluble in water and its susceptibility to corrosion in the oral environment is negligible [118-121]. Among the various metal-free, ceramic materials, after conventional finishing and polishing, monolithic zirconia exhibits the lowest wear behaviour towards opponent teeth [123].

\section{Phase transformation toughening (PTT)}

In dentistry, zirconia is usually considered an all-ceramic material but, from the physical-chemical point of view, it is a metal oxide with ceramic properties characterized by polymorphism and allotropy. In fact, it is present in nature with three different crystalline configurations at different temperatures: cubic (from the melting point at $2680{ }^{\circ} \mathrm{C}$ to $2370^{\circ} \mathrm{C}$ ), tetragonal (from $2370^{\circ} \mathrm{C}$ to $1170{ }^{\circ} \mathrm{C}$ ) and monoclinic (from $1170^{\circ} \mathrm{C}$ to room temperature). These different allotropic states present with distinct mechanical and optical properties that can be exploited differently in Prosthodontics [118-121, 124].

Conventionally, zirconia is mainly used in its partially yttria-stabilized tetragonal phase (Y-TZP) as a prosthetic material for indirect restorations. Under the effect of mechanical, thermal and/or combined stresses, the adsorbed energy can break part of the atomic bonds of its polycrystalline structure turning such tetragonal crystals to a stabler monoclinic shape. This spontaneous and irreversible transformation is known as Phase Transformation Toughening (PTT) and shows a contemporary 4-5\% increase in crystals volume, creating significant compressive stresses within the material [118-121, 124].

From the technological and prosthetic sides, the PTT has been advertised as a paramount advantage, since it allows a kind of self-repairability of zirconia; indeed, it permits to block or at least to hinder the propagation of micro-cracks and fractures within the material. In fact, the subsequent volumetric increment of the crystals generates comses within the material at the fracture tip, limiting crack propagation [118-121, 124-126]. It is worth noticing that at room temperature such transformation is irreversible and localized, centered at the stress bearing area (i.e. occlusal load area, traumatic impact zone, etc.): once the limiting action of the fracture propagation has occurred, in its monoclinic configuration zirconia is no longer able to limit cracks any further $[119,124,126]$. On the contrary, heating monoclinic zirconia again up to $900-1000{ }^{\circ} \mathrm{C}$ (for limited time according to manufacturers' instructions), the PTT becomes reversible: by means of a process called "regeneration" or "annealing", monoclinic crystals can be moved back to the tetragonal phase, causing the relaxation of compressive stresses within the material $[125,126]$. After annealing, however, zirconia toughness tends to be reduced and, as regards the optical properties, a chromatic oversaturation can occur; consequently, thermal treatments at high temperature should be used carefully and only after potentially aggressive mechanical procedures (i.e. relevant occlusal grinding, polishing, etc.) [126-128].

In order to profit from the positive features of the PTT intraorally, during industrial manufacturing cubic and tetragonal zirconia are stabilized with metal oxides, just like yttrium, magnesium, cerium and lanthanum; the percentage of such dopants can vary according to manufacturing techniques and clinical use. These stabilizing oxides contribute to keep zirconia in its crystalline tetragonal phase also at room temperature in a thermodynamically metastable state, preventing the spontaneous transformation in the more stable monoclinic crystals. However, such dopant oxides can get lost after traumatic events, surface modifications (i.e. occlusal adjustments, grinding, polishing, etc.) and material aging [118-121, 124-127].

\section{Low temperature degradation (LTD) and aging}

In turn, the PTT is closely related to a negative phenomenon, the so-called "Low Temperature Degradation (LTD)", responsible for zirconia aging. At room temperature, the material can undergo a spontaneous and irreversible transformation to the monoclinic phase, even in the absence of any mechanical stress. This phenomenon causes a worsening of mechanical properties, till the possible occurrence of spontaneous fractures [118-121, 124-127, 129, 130]. The LTD is a multifactorial phenomenon affected by several variables, such as crystals dimension, temperature, surface defects, manufacturing techniques, percentage and distribution of stabilizing oxides, mechanical stress and wetness; particularly, the last two factors can significantly accelerate zirconia aging. Although aging is considered a risk factor for mechanical failure, to date no univocal correlation has been evidenced between this phenomenon and the failures affecting zirconia during clinical service. Nonetheless, the LTD is known to cause a worsening of zirconia characteristics, contributing to the onset of micro-cracks, toughness reduction, increased wear, roughening and plaque accumulation, till a severe surface degradation, affecting both mechanical and optical properties [118-121, 125-127, 129, 130].

As reported in a recent in vitro study, monolithic tetragonal zirconia restorations can undergo hydrothermal degradation (i.e. aging) also after short observation times; however, such phenomenon does not reduce significantly the mechanical properties of tetragonal zirconia even in 
the presence of wide monoclinic transformed areas [126]. In the same research, the glassy layer used for glazing effect can act as a protective barrier against hydrothermal degradation; nonetheless, some restoration areas, particularly at the margins, can show absence of glazing protection and subsequently can be more susceptible to aging [126].

In vitro studies have clearly demonstrated that mechanical properties of zirconia, expressed by parameters like load-to-fracture values, are higher than those of $\mathrm{LS}_{2}$, which, from their part, are higher than those of ZLS; the number of fatigue loading cycles does not seem to affect the load-to-fracture of zirconia restorations [23].

\section{Optical and mechanical properties}

Laboratory investigations reported that monolithic zirconia restorations showed higher resistance to fracture than bilayered ones, even after mechanical cycling and aging [131-136]. Surface finishing techniques did not influence mechanical performance [132], neither did cementation techniques, particularly onto implants [137]; on the contrary, fracture resistance has been reported to be significantly influenced by preparation design [138, 139] and low temperature degradation [138], so it can be inferred that material and geometrical characteristics are crucial to optimize longevity of monolithic zirconia restorations [140]. The high mechanical reliability of zirconia has been confirmed by recent in vitro analyses, demonstrating that monolithic zirconia crowns with occlusal thickness of $0.5 \mathrm{~mm}$ exhibit sufficient fracture resistance to withstand occlusal loads in the molar regions [134, 135]. Moreover, increasing the content of yttrium oxide to improve the optical properties of zirconia can reduce mechanical properties after aging, although fracture resistance was reported to be higher than masticatory loads $(3000 \mathrm{~N})$ [141].

Zirconia is usually considered as an opaque restorative material with optical and esthetic properties less attractive than glassy ceramics, particularly in terms of translucency. By means of transillumination, it has been shown that tetragonal zirconia allows only about $25 \%$ of incident light to pass through; this characteristic can be advantageously used to mask dark substrates (i.e. metal posts/abutments, dark teeth, etc.) [126, 127, 142-144].

Recently, in order to enhance the esthetic properties of the material, translucent zirconia has been introduced in the market, characterized by the presence of $30-35 \%$ of cubic crystals. Besides the improved optical characteristics, in the presence of such cubic phase no hydrothermal degradation (i.e. aging) of this allotropic component is evidenced. However, apart from the better optical properties, the toughness of translucent zirconia is reduced, compared to tetragonal one, with values of flexural strength ranging between 500 and $900 \mathrm{MPa}$; as a consequence, translucent zirconia represents a suitable esthetic and mechanical compromise to be preferred in anterior areas up to the first premolars in its monolithic configuration [126, 142, 143]. As demonstrated by a recent investigation, the reduced mechanical properties of translucent zirconia are due to the dimensions and distribution of the crystals: in fact, cubic grains present with wider dimensions than tetragonal ones and segregate a higher amount of stabilizing oxides, making the tetragonal phase more prone to aging [126].

\section{Manufacturing procedures}

Although new additive technologies are emerging from the research on dental materials, to date, zirconia is still fabricated by CAD-CAM milling, according to two different production techniques: either soft machining of pre-sintered zirconia or hard machining of fully-sintered zirconia. Both procedures can be accomplished in industrial milling centers, in dental laboratories or by chairside devices [118-121, 124, 127].

Soft machining represents the most popular manufacturing technique and is based on milling of pre-sintered zirconia blanks fabricated by cold-isostatic pressing a mixture of zirconia powder, stabilizing oxides and binding agents (the latter removed during the pre-sintering process). With this technique, zirconia is highly homogenous and easier to mill, reducing production times, machinery wear and surface flaws; furthermore, soft machining generates negligible internal porosities (about $20-30 \mathrm{~nm}$ ). The downside is that this process requires a $25 \%$ oversizing of the framework to be milled, since following sintering a linear shrinkage of the final volume occurs; as a consequence, although milling procedures are easier, soft machining requires a precise matching of CAD oversizing and material shrinking in order to avoid dimensional inaccuracies, particularly in the presence of complex framework geometry [118-121, $125,127]$.

Viceversa, hard machining requires milling of fullysintered zirconia blanks generally produced with hot isostatic pressing (HIP) at $1400^{\circ}-1500^{\circ} \mathrm{C}$. This approach eliminates the problem of post-milling shrinkage, since neither oversizing nor sintering are necessary; however, hard machining needs longer milling times and more complex manufacturing, involving higher costs due to accelerated wear of production machinery and increased risks of attrition flaws. In addition, right after hard machining, zirconia frameworks can undergo a certain amount of monoclinic transformation phase due to mechanical stress, working burs friction and overheating subsequent to machining of the hard material [118-121, $125,127]$.

Literature data are still controversial about which technique is the best, being the choice mainly guided by the operator preference, according to considerations related 
to shape, volume and complexity of the prosthetic geometry as well as time and cost of the milling procedures [118-121, 127].

High temperature and prolonged sintering time generate bigger zirconia crystals and the dimension of such grains significantly influences the mechanical properties of the material. In fact, the critical crystal dimension is about $1 \mathrm{~mm}$ : above this diameter, zirconia becomes spontaneously more susceptible to PTT, while under 0.2 $\mathrm{mm}$ such phenomenon does not occur and the toughness of the material decreases. Consequently, fabrication procedures (particularly sintering) significantly affect mechanical properties and stability of zirconia and have to be carefully checked during the whole manufacturing process $[126,127,129,130,142]$.

In order to get a proper color of the restorations, specific metal oxides can be used as stains within the pre-sintering zirconia powder mixture or metallic salts can be infiltrated after milling; moreover, zirconia blanks are also available in multilayered color configurations. It has been clearly demonstrated that the coloring process does not influence mechanical properties of tetragonal zirconia, whilst uncertainty still remains regarding translucent cubic crystals [118-121, 125, 127, 129, 130].

Zirconia can be fabricated in monolithic or layered configurations. The monolithic material, not veneered with any ceramic layer, shows a less attractive esthetic appearance, but is not affected by the frequent cohesive fractures of the layering ceramics, known as "chipping" $[134,145]$.

To date, scientific evidences support the use of monolithic zirconia in posterior regions and in not esthetically relevant areas of the anterior arch (i.e. lingual tooth surfaces), while the use of layered restorations should be mainly addressed in highly esthetic zones [134, 145149]. The minimum thickness suitable for monolithic YTZP restorations is $0.5 \mathrm{~mm}$ [134]; as regards layered prostheses, the total thickness ranges between 1.0 and $1.5 \mathrm{~mm}[134,145-149]$. In order to optimize mechanical resistance of layered restorations, it is paramount that veneering ceramics exhibit zirconia-compatible CTE $[128,150]$.

\section{Marginal accuracy and internal fit}

The accuracy of zirconia prostheses can be influenced by several factors, such as manufacturing, complexity of framework geometry (i.e. marginal finish line, span length, connectors dimension, etc.) and aging. The comparison of data regarding internal precision and marginal fit of zirconia is quite difficult, as literature data are heterogeneous and study designs are different for both laboratory and clinical investigations [119, 120, 127]. To date, it is possible to state that marginal precision of zirconia restorations is better than internal fit (probably because of the shape/size of the CAD-CAM milling burs) and that, in any case, precision values are well within the range of clinical acceptability reported in the specifications of the American Dental Association (ADA). Marginal gap values have been reported between 0 and $75 \mathrm{~mm}$ for SCs $[151,152]$ and $140 \mathrm{~mm}$ for FDPs, the latter showing an increasing proportional to framework span [119, 120, 127, 153].

As regards preparation geometry, the high stability and structural resistance of zirconia are compatible with both vertical and horizontal finish lines [124, 153].

\section{Surface treatment and cementation}

Due to the absence of any glassy matrix, zirconia is free from silica and, consequently, cannot be conditioned with conventional acid etching techniques, differently from glass-ceramics $[119,122]$. Several surface treatments aimed at getting a reliable bond to the substrate have been reported in the literature but to date this topic is still controversial [154-163]. Aggressive sandblasting (i.e. $250 \mathrm{~mm}$ alumina particles at $0.4 \mathrm{MPa}$ ) can cause loss of the stabilizing oxides with a subsequent increased risk of accelerated PTT and aging of the material; as a consequence, it would be advisable to treat zirconia surfaces with milder sandblasting, using $110 \mathrm{~mm}$ alumina particles at $0.2 \mathrm{MPa}$. Such treatment can be advantageous for partially stabilized zirconia (PSZ) while it seems to weaken the fully stabilized material (FSZ) [155, 156, 158, 159, 163].

The use of coupling agents like silane can be adopted only after a tribochemical conditioning with silica-coated alumina particles or after infiltrating the zirconia surface with a thin layer of glassy ceramics [154, 155, 161]; however, the latter approach can determine the creation of excessive ceramic thickness and the effectiveness of adhesion between the glassy matrix and the polycrystalline network still remains unclear [154, 155, 158, 161].

The combination of mechanical and chemical treatments of zirconia surface was proved to offer the best results; particularly, the use of primers and adhesion promoting agents containing acidic monomers (10-MDP) can have a synergic effect with silane, improving the effectiveness of simplified adhesive techniques [155, 160-163].

On the basis of the physical-chemical properties of zirconia, in the presence of retentive preparation geometries and full coverage prostheses, conventional water-based luting agents (i.e. glass-ionomer and zinc phosphate cements) and hybrid cements (i.e. resinmodified glass-ionomer cements) can be considered a good choice for cementation. Otherwise, in the presence of partial coverage restorations, scarcely retentive preparation geometries (e.g. abutment teeth with reduced occluso-cervical dimension) and/or high masticatory loads, besides the above mentioned conditioning treatments of zirconia surface, it is possible to use 
conventional resin cement or simplified self-adhesive luting agents, so as to allow resin better adsorb, distribute occlusal forces and withstand possible micro-cracks on the inner surface of the restorations $[155,158,162]$.

\section{Clinical indication and performances}

From a clinical point of view, in the last decades zirconia has more and more gained ground in the realm of metal-free, mainly utilized to restore both natural teeth and osseointegrated implants with SCs and short- and medium-span FDPs up to 5 elements $[134,145,146$, $148,149,164,165]$. As regards FDPs, besides the high mechanical properties of the material, fracture resistance and clinical performance are also strongly related to a proper framework architecture. In case of bilayered FDPs, in particular, an "anatomic" design has to be performed, ensuring proper support and thickness to the veneering; moreover, connectors are to be designed with adequate dimensions (minimum area of section: 9, 15 and $25 \mathrm{~mm}^{2}$ for 3-, 4- and 5-unit FDPs respectively) and with rounded interdental embrasures, in order to avoid sharp angles that can contribute to generate risky stress concentration [146]. The presence of an adequate occlusal support is a relevant factor in maintaining an efficient chewing [166]; consequently, due to the absence of veneering ceramics that could be subjected to wear over time, monolithic restorations could be helpful in keeping occlusal stability during clinical service, particularly in the presence of discrepancies in occlusal contact patterns that could influence the onset of temporo-mandibular disorders [167].

Recently, clinical investigations regarding tooth- and implant-supported full-arch restorations have been published [165]. Although short- and medium-term results were encouraging with $94.8 \%$ success rate after 3 years of clinical service for monolithic full-arch bridges [145], it is worth noticing that a systematic review of the literature has reported 5-year complication rates of 27.6 and $30.5 \%$, respectively for tooth-supported and implantsupported full-arch restorations [168]. Moreover, layered restorations showed 5-year success rates significantly lower than monolithic prostheses (i.e. $60.4 \%$ vs $90.9 \%$ ) [169]. Consequently, the use of full-arch, extended zirconia restorations should always be carefully evaluated and further long-term clinical studies are necessary to validate the effectiveness of their serviceability.

As regards zirconia implants, the literature reports controversial, short-term and mainly anecdotal data $[165,170-174]$. A recent systematic review with metaanalysis has evidenced similar potentialities of hard- and soft-tissue integration between zirconia and titanium implants, although with a slower initial osseointegration process detected in zirconia ones. In any case, the use of the latter should be cautiously evaluated, until more light is shed on long term outcomes and, particularly, on the possible mechanical complications. Viceversa, zirconia abutments are to be considered widely validated today in the esthetic sites, where the clear color of zirconia contributes to achieve a natural aspect of periimplant soft tissues, particularly when they are quite thin $[127,148,165,172,173]$. A retrospective clinical study on a relevant number of ceramic abutments reported that internal zirconia implant connections are much more prone to mechanical complications (i.e. unscrewing, fractures, etc.) than hybrid connections with zirconia abutments cemented onto titanium bases; moreover, the same investigation reported that the distance between the implant/abutment connection and the occlusal plane can significantly influence the onset of bending moments that can be detrimental for the longterm prognosis of metal-free restorations [172].

\section{Conclusions}

At the moment, it can be stated that silicate- and zirconia-based ceramics are amongst the most versatile metal-free materials available for the "digital prosthodontic environment". In the last years, an increasing amount of available in vitro and in vivo data is shedding precious light on the outline of guidelines for a restorative rational use, focused on specific materials advantages and limitations, taking into account mechanical, optical and biological properties in the light of a widespread clinical experience (Table 1). In the meanwhile, the world of industry is intensively

Table 1 Lithium disilicate and zirconia: pros and cons

\begin{tabular}{|c|c|}
\hline Lithium disilicate & \\
\hline Pros & Cons \\
\hline $\begin{array}{l}\text { - excellent optical } \\
\text { characteristics and good } \\
\text { mechanical properties } \\
\text { - clinical versatility } \\
\text { - biocompatibility } \\
\text { - favourable abrasiveness } \\
\text { - marginal accuracy and } \\
\text { internal fit } \\
\text { - high strength of adhesion } \\
\text { to the substrate } \\
\text { - monolithic and layered }\end{array}$ & $\begin{array}{l}\text { - glaze coating and fluorapatite } \\
\text { ceramic veneering can } \\
\text { increase wear } \\
\text { - critical to adjust intraorally } \\
\text { - chipping of the veneering } \\
\text { ceramics }\end{array}$ \\
\hline conia & \\
\hline Pros & Cons \\
\hline $\begin{array}{l}\text { - excellent mechanical } \\
\text { characteristics and } \\
\text { good optical properties } \\
\text { - excellent biocompatibility } \\
\text { and low plaque } \\
\text { retention } \\
\text { - favourable wear behaviour } \\
\text { - implant abutments for esthetic sites } \\
\text { - crack-hindering potential (through PTT) } \\
\text { - marginal accuracy and internal fit } \\
\text { - monolithic and layered }\end{array}$ & $\begin{array}{l}\text { - opacity } \\
\text { - unetchable with } \\
\text { conventional methods } \\
\text { - low temperature degradation } \\
\text { and aging } \\
\text { - critical to adjust intraorally } \\
\text { - glaze coating and fluorapatite } \\
\text { ceramic veneering can } \\
\text { increase wear } \\
\text { - chipping of the } \\
\text { veneering ceramics }\end{array}$ \\
\hline
\end{tabular}


working on new strategies aimed at further enhancing microstructural characteristics of these materials, together with the introduction of new production technologies, mainly based on additive processes.

\section{Abbreviations}

10-MDP: 10-Methacryloyloxydecyl-Dihydrogen-Phosphate; ADA: American Dental Association; $\mathrm{Ca}_{5}\left(\mathrm{PO}_{4}\right)_{3} \mathrm{~F}$ : Fluorapatite crystals; CAD-CAM: Computeraided design/computer-aided manufacturing; CEJ: Cemento-enamel junction; CTE: Coefficient of thermal expansion; FDPs: Fixed dental prostheses; FSZ: Fully stabilized zirconia; HF: Hydrofluoric acid; HIP: Hot isostatic pressing; $\mathrm{KIC}$ : Fracture toughness; $\mathrm{Li}_{2} \mathrm{Si}_{2} \mathrm{O}_{5}$ : Lithium disilicate crystal nuclei; $\mathrm{Li}_{2} \mathrm{SiO}_{3}$ : Metasilicates; LS: Lithium disilicate; LTD: Low Temperature Degradation; PEEK: Polyether ether ketone; PSZ: Partially stabilized zirconia; PTT: Phase Transformation Toughening; RBFDPs: Resin-bonded fixed dental prostheses; SCs: Single crowns; SEM: Scanning electron microscope; YTZP: Yttria stabilized tetragonal zirconia; ZLS: Zirconia reinforced-Lithium Sili cate ceramics; $\mathrm{ZrO}_{2}$ : Zirconia

\section{Publisher's Note}

Springer Nature remains neutral with regard to jurisdictional claims in published maps and institutional affiliations.

\section{Acknowledgements}

Not applicable.

\section{Authors' contributions}

MIDM and GR acquired and analyzed all the papers included in the present review and performed the preparation of the manuscript; FZ, PA and RS revised the work and approved the submitted version. All authors read and approved the final manuscript.

\section{Funding}

Not applicable.

\section{Availability of data and materials}

Not applicable.

\section{Ethics approval and consent to participate} Not applicable.

\section{Consent for publication}

The authors give their consent for publication.

\section{Competing interests}

The authors declare that they have no competing interests.

Received: 24 April 2019 Accepted: 27 June 2019

Published online: 04 July 2019

\section{References}

1. Albakry M, Guazzato M, Swain MV. Influence of hot pressing on the microstructure and fracture toughness of two pressable dental glassceramics. J Biomed Mater Res B Appl Biomater. 2004;71(1):99-107.

2. Denry I, Holloway JA. Ceramics for dental applications: a review. Materials. 2010;3:351-68

3. Zarone F, Ferrari M, Mangano FG, Leone R, Sorrentino R. "Digitally oriented materials": focus on lithium disilicate ceramics. Int J Dent 2016;2016:9840594

4. Fischer K, Bühler-Zemp P, Völkel T. Scientific Documentation IPS e.max CAD. Schaan, Liechtenstein: Ivoclar Vivadent; 2005. p. 1-30.

5. Willard A, Gabriel Chu TM. The science and application of IPS e. max dental ceramic. Kaohsiung J Med Sci. 2018;34(4):238-42

6. Vivadent I. IPS e. max lithium disilicate: the future of all- ceramic dentistry material science, practical applications, keys to success. Amherst, NY: Ivoclar Vivadent; 2009. p. 1e15.

7. Fabian Fonzar R, Carrabba M, Sedda M, Ferrari M, Goracci C, Vichi A. Flexural resistance of heat-pressed and CAD-CAM lithium disilicate with different translucencies. Dent Mater. 2017;33(1):63-70.
8. Belli R, Geinzer E, Muschweck A, Petschelt A, Lohbauer U. Mechanical fatigue degradation of ceramics versus resin composites for dental restorations. Dent Mater. 2014;30(4):424-32.

9. Furtado de Mendonca A, Shahmoradi M, Gouvêa CVD, De Souza GM Ellakwa A. Microstructural and mechanical characterization of CAD/ CAM materials for monolithic dental restorations. J Prosthodont. 2019; 28(2):e587-94.

10. Guess PC, Zavanelli RA, Silva NR, Bonfante EA, Coelho PG, Thompson VP. Monolithic CAD/CAM lithium disilicate versus veneered Y-TZP crowns: comparison of failure modes and reliability after fatigue. Int J Prosthodont. 2010;23(5):434-42

11. Lien W, Roberts HW, Platt JA, Vandewalle KS, Hill TJ, Chu TM. Microstructural evolution and physical behavior of a lithium disilicate glass-ceramic. Dent Mater. 2015;31:928-40

12. Al Mansour F, Karpukhina N, Grasso S, Wilson RM, Reece MJ, Cattell MJ. The effect of spark plasma sintering on lithium disilicate glass-ceramics. Dent Mater. 2015:31(10):e226-35.

13. Kubatík TF, Lukáč F, Mušálek R, Brožek V, Stehlíková K, Chráska T. Compaction of lithium-silicate ceramics using spark plasma sintering. Ceramics-Silikáty. 2017;61(1):40-4.

14. Zhao K, Wei YR, Pan Y, Zhang XP, Swain MV, Guess PC. Influence of veneer and cyclic loading on failure behavior of lithium disilicate glass-ceramic molar crowns. Dent Mater. 2014;30(2):164-71

15. Silva NR, Thompson VP, Valverde GB, Coelho PG, Powers JM, Farah JW, Esquivel-Upshaw J. Comparative reliability analyses of zirconium oxide and lithium disilicate restorations in vitro and in vivo. J Am Dent Assoc. 2011; 142(Suppl 2):4S-9S.

16. Schultheis S, Strub JR, Gerds TA, Guess PC. Monolithic and bi-layer CAD/ CAM lithium disilicate versus metalceramic fixed dental prostheses: comparison of fracture loads and failure modes after fatigue. Clin Oral Investig. 2013;17(5):1407-13.

17. Kim JH, Lee SJ, Park JS, Ryu J. Fracture load of monolithic CAD/CAM lithium disilicate ceramic crowns and veneered zirconia crowns as a posterior implant restoration. Implant Dent. 2013;22(1):66-70.

18. Monaco C, Rosentritt M, Llukacej A, Baldissara P, Scotti R. Marginal adaptation, gap width, and fracture strength of teeth restored with different all-ceramic vs metal ceramic crown systems: an in vitro study. Eur J Prosthodont Restor Dent. 2016;24(3):130-7.

19. Dogan DO, Gorler O, Mutaf B, Ozcan M, Eyuboglu GB, Ulgey M. Fracture resistance of molar crowns fabricated with monolithic all-ceramic CAD/CAM materials cemented on titanium abutments: an in vitro study. J Prosthodont. 2017;26(4):309-14.

20. Hamza TA, Sherif RM. Fracture resistance of monolithic glass-ceramics versus bilayered zirconia-based restorations. J Prosthodont. 2019;28(1):e259-64.

21. Choi JW, Kim SY, Bae JH, Bae EB, Huh JB. In vitro study of the fracture resistance of monolithic lithium disilicate, monolithic zirconia, and lithium disilicate pressed on zirconia for three-unit fixed dental prostheses. J Adv Prosthodont. 2017;9(4):244-51.

22. Alsarani M, Souza G, Rizkalla A, El-Mowafy O. Influence of crown design and material on chipping-resistance of all-ceramic molar crowns: an in vitro study. Dent Med Probl. 2018:55(1):35-42.

23. Kashkari A, Yilmaz B, Brantley WA, Schricker SR, Johnston WM. Fracture analysis of monolithic CAD-CAM crowns. J Esthet Restor Dent. 2019. https:// doi.org/10.1111/jerd.12462

24. Nawafleh N, Hatamleh M, Elshiyab S, Mack F. Lithium disilicate restorations fatigue testing parameters: a systematic review. J Prosthodont. 2016;25(2):116-26.

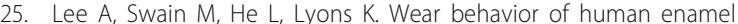
against lithium disilicate glass ceramic and type III gold. J Prosthet Dent. 2014;112:1399-405.

26. Kim MJ, Oh SH, Kim JH, Ju SW, Seo DG, Jun SH, Ahn JS, Ryu JJ. Wear evaluation of the human enamel opposing different Y-TZP dental ceramics and other porcelains. J Dent. 2012:40(11):979-88.

27. Amer R, Kürklü D, Kateeb E, Seghi RR. Three-body wear potential of dental yttrium-stabilized zirconia ceramic after grinding, polishing, and glazing treatments. J Prosthet Dent. 2014;112(5):1151-5.

28. Zurek AD, Alfaro MF, Wee AG, Yuan JC, Barao VA, Mathew MT, Sukotjo C. Wear characteristics and volume loss of CAD/CAM ceramic materials. J Prosthodont. 2019:28(2):e510-8.

29. Preis $V$, Weiser F, Handel G, Rosentritt M. Wear performance of monolithic dental ceramics with different surface treatments. Quintessence Int. 2013:44: 393-405. 
30. Mörmann WH, Stawarczyk B, Ender A, Sener B, Attin T, Mehl A. Wear characteristics of current aesthetic dental restorative CAD/CAM materials: two-body wear, gloss retention, roughness and martens hardness. J Mech Behav Biomed Mater. 2013;20:113-25.

31. Peng Z, Izzat Abdul Rahman M, Zhang Y, Yin L. Wear behavior of pressable lithium disilicate glass ceramic. J Biomed Mater Res B Appl Biomater. 2016; 104(5):968-78

32. Song XF, Ren HT, Yin L. Machinability of lithium disilicate glass ceramic in in vitro dental diamond bur adjusting process. J Mech Behav Biomed Mater. 2016;53:78-92

33. Figueiredo-Pina CG, Patas N, Canhoto J, Cláudio R, Olhero SM, Serro AP, Ferro AC, Guedes M. Tribological behaviour of unveneered and veneered lithium disilicate dental material. J Mech Behav Biomed Mater. 2016;53:226-38.

34. Forster A, Ungvári K, Györgyey Á, Kukovecz Á, Turzó K, Nagy K. Human epithelial tissue culture study on restorative materials. J Dent. 2014; 42(1):7-14.

35. Tetè S, Zizzari VL, Borelli B, De Colli M, Zara S, Sorrentino R, Scarano A, Gherlone E, Cataldi A, Zarone F. Proliferation and adhesion capability of human gingival fibroblasts onto zirconia, lithium disilicate and feldspathic veneering ceramic in vitro. Dent Mater J. 2014;33(1):7-15.

36. Ariaans K, Heussen N, Schiffer $H$, Wienert AL, Plümäkers B, Rink L, Wolfart S Use of molecular indicators of inflammation to assess the biocompatibility of all-ceramic restorations. J Clin Periodontol. 2016;43(2):173-9.

37. Baldissara P, Llukacej A, Ciocca L, Valandro FL, Scotti R. Translucency of zirconia copings made with different CAD/CAM systems. J Prosthet Dent. 2010;104(1):6-12.

38. Murillo-Gómez F, Palma-Dibb RG, De Goes MF. Effect of acid etching on tridimensional microstructure of etchable CAD/CAM materials. Dent Mater. 2018;34(6):944-55.

39. Bajraktarova-Valjakova E, Grozdanov A, Guguvcevski L, Korunoska-Stevkovska V, Kapusevska B, Gigovski N, Mijoska A, Bajraktarova-Misevska C. Acid etching as surface treatment method for luting of glass-ceramic restorations, part 1: acids, application protocol and etching effectiveness. Open Access Maced J Med Sci. 2018;6(3):568-73.

40. Prochnow C, Venturini AB, Guilardi LF, Pereira GKR, Burgo TAL, Bottino MC, Kleverlaan CJ, Valandro LF. Hydrofluoric acid concentrations: effect on the cyclic load-to-failure of machined lithium disilicate restorations. Dent Mater. 2018;34(9):e255-63.

41. Sundfeld D, Palialol ARM, Fugolin APP, Ambrosano GMB, Correr-Sobrinho L, Martins LRM, Pfeifer CS. The effect of hydrofluoric acid and resin cement formulation on the bond strength to lithium disilicate ceramic. Braz Oral Res. 2018;32:e43.

42. Ataol AS, Ergun G. Repair bond strength of resin composite to bilayer dental ceramics. J Adv Prosthodont. 2018;10(2):101-12.

43. Menees TS, Lawson NC, Beck PR, Burgess JO. Influence of particle abrasion or hydrofluoric acid etching on lithium disilicate flexural strength. J Prosthet Dent. 2014;112(5):1164-70.

44. Blatz MB, Sadan A, Kern M. Resin-ceramic bonding: a review of the literature. J Prosthet Dent. 2003;89(3):268-74.

45. Carvalho AO, Bruzi G, Giannini M, Magne P. Fatigue resistance of CAD/CAM complete crowns with a simplified cementation process. J Prosthet Dent. 2014;111:310-7.

46. Fabbri G, Sorrentino R, Brennan M, Cerutti A. A novel approach to implant screw-retained restorations: adhesive combination between zirconia frameworks and monolithic lithium disilicate. Int J Esthet Den. 2014;9:490-505.

47. Frankenberger R, Hartmann VE, Krech M, Krämer N, Reich S, Braun A, Roggendorf M. Adhesive luting of new CAD/CAM materials. Int J Comput Dent. 2015;18:9-20.

48. Neis CA, Albuquerque NL, Albuquerque Ide S, Gomes EA, Souza-Filho CB, Feitosa VP, Spazzin AO, Bacchi A. Surface treatments for repair of feldspathic, leucite - and lithium disilicate-reinforced glass ceramics using composite resin. Braz Dent J. 2015:26(2):152-5.

49. Carvalho AO, Bruzi G, Anderson RE, Maia HP, Giannini M, Magne P. Influence of adhesive core buildup designs on the resistance of endodontically treated molars restored with lithium disilicate CAD/CAM crowns. Oper Dent. 2016:41:76-82.

50. Swank HM, Motyka NC, Bailey CW, Vandewalle KS. Bond strength of resin cement to ceramic with simplified primers and pretreatment solutions. Gen Dent. 2018;66(5):33-7.
51. Taguchi S, Komine F, Kubochi K, Fushiki R, Kimura F, Matsumura H. Effect of a silane and phosphate functional monomer on shear bond strength of a resin-based luting agent to lithium disilicate ceramic and quartz materials. J Oral Sci. 2018;60(3):360-6.

52. Gehrt M, Wolfart S, Rafai N, Reich S, Edelhoff D. Clinical results of lithium-disilicate crowns after up to 9 years of service. Clin Oral Investig. 2013;17(1):275-84.

53. Spies BC, Pieralli S, Vach K, Kohal RJ. CAD/CAM-fabricated ceramic implant-supported single crowns made from lithium disilicate: final results of a 5-year prospective cohort study. Clin Implant Dent Relat Res. 2017;19(5):876-83.

54. Joda T, Ferrari M, Brägger U. Monolithic implant-supported lithium disilicate (LS2) crowns in a complete digital workflow: a prospective clinical trial with a 2-year follow-up. Clin Implant Dent Relat Res. 2017:19(3):505-11.

55. Fabbri G, Zarone F, Dellificorelli G, Cannistraro G, De Lorenzi M, Mosca A, Sorrentino R. Clinical evaluation of 860 anterior and posterior lithium disilicate restorations: retrospective study with a mean follow-up of 3 years and a maximum observational period of 6 years. Int J Periodontics Restorative Dent. 2014;34(2):165-77.

56. Simeone $\mathrm{P}, \mathrm{Gracis} \mathrm{S}$. Eleven-year retropective survival study of 275 veneered lithium disilicate single crowns. Int J Periodontics Restorative Dent. 2015; 35(5):685-94.

57. Valenti M, Valenti A. Retrospective survival analysis of 110 lithium disilicate crowns with feather-edge marginal preparation. Int J Esthet Dent. 2015 10(2):246-57.

58. van den Breemer $C R$, Vinkenborg $C$, van Pelt $H$, Edelhoff $D$, Cune MS. The clinical performance of monolithic lithium disilicate posterior restorations after 5, 10, and 15 years: a retrospective case series. Int J Prosthodont. 2017; 30(1):62-5.

59. Rauch A, Reich S, Dalchau L, Schierz O. Clinical survival of chair-side generated monolithic lithium disilicate crowns:10-year results. Clin Oral Investig. 2018;22(4):1763-9.

60. Pozzi A, Tallarico M, Barlattani A. Monolithic lithium disilicate fullcontour crowns bonded on CAD/CAM zirconia complete-arch implant bridges with 3 to 5 years of follow-up. J Oral Implantol. 2015;41(4): 450-8.

61. Atsü SS, Aksan ME, Bulut AC. Fracture resistance of titanium, zirconia, and ceramic-reinforced polyetheretherketone implant abutments supporting CAD/CAM monolithic lithium disilicate ceramic crowns after aging. Int J Oral Maxillofac Implants. 2019;34(3):622-30.

62. Radz GM. Minimum thickness anterior porcelain restorations. Dent Clin N Am. 2011;55(2):353-70 ix

63. Ge C, Green CC, Sederstrom D, McLaren EA, White SN. Effect of porcelain and enamel thickness on porcelain veneer failure loads in vitro. J Prosthet Dent. 2014;111(5):380-7.

64. Ge C, Green CC, Sederstrom DA, MCLaren EA, Chalfant JA, White SN. Effect of tooth substrate and porcelain thickness on porcelain veneer failure loads in vitro. J Prosthet Dent. 2018;120(1):85-91.

65. Sorrentino R, Apiucela D, Riccio C, Gherlone E, Zarone F, Aversa R, Garcia-Godoy F, Ferrari M, Apicella A. Nonlinear visco-elastic finite element analysis of different porcelain veneers configuration. J Biomed Mater Res B Appl Biomater. 2009:91(2):727-36.

66. Kern M, Knode H, Strub JR. The all-porcelain, resin-bonded bridge. Quintessence Int. 1991;22(4):257-62.

67. Kern M, Strub JR. Bonding to alumina ceramic in restorative dentistry: clinical results over up to 5 years. J Dent. 1998;26(3):245-9.

68. Kern M. Clinical long-term survival of two-retainer and single-retainer all-ceramic resin-bonded fixed partial dentures. Quintessence Int. 2005; 36(2):141-7.

69. Kern M, Sasse M. Ten-year survival of anterior all-ceramic resin-bonded fixed dental prostheses. J Adhes Dent. 2011:13(5):407-10.

70. Kern M, Gläser R. Cantilevered all-ceramic, resin-bonded fixed partial dentures: a new treatment modality. J Esthet Dent. 1997:9(5):255-64.

71. Kern M. Fifteen-year survival of anterior all-ceramic cantilever resin-bonded fixed dental prostheses. J Dent. 2017:56:133-5.

72. Sasse M, Kern M. CAD/CAM single retainer zirconia-ceramic resin-bonded fixed dental prostheses: clinical outcome after 5 years. Int J Comput Dent. 2013;16(2):109-18

73. Sailer I, Hämmerle $\mathrm{CH}$. Zirconia ceramic single-retainer resin-bonded fixed dental prostheses (RBFDPs) after 4 years of clinical service: a retrospective 
clinical and volumetric study. Int J Periodontics Restorative Dent. 2014;34(3): 333-43.

74. Sasse M, Kern M. Survival of anterior cantilevered all-ceramic resinbonded fixed dental prostheses made from zirconia ceramic. J Dent. 2014;42(6):660-3.

75. Klink A, Hüttig F. Zirconia-based anterior resin-bonded single-retainer cantilever fixed dental prostheses: a 15- to 61-month follow-up. Int J Prosthodont. 2016;29(3):284-6.

76. Sun Q, Chen L, Tian L, Xu B. Single-tooth replacement in the anterior arch by means of a cantilevered IPS e.max press veneer-retained fixed partial denture: case series of 35 patients. Int J Prosthodont. 2013;26:181-7.

77. Sailer I, Bonani T, Brodbeck U, Hämmerle CH. Retrospective clinical study of single-retainer cantilever anterior and posterior glass-ceramic resin-bonded fixed dental prostheses at a mean follow-up of 6 years. Int J Prosthodont. 2013;26(5):443-50

78. Zhou T, Wang X, Zhang G. All-ceramic resin bonded fixed partial denture made of IPS hot-pressed casting porcelain restore anterior missing teeth: a three years clinical observation. Beijing Da Xue Xue Bao. 2011;43(1):77-80.

79. Wei YR, Wang XD, Zhang Q, Li XX, Blatz MB, Jian YT, Zhao K. Clinical performance of anterior resin-bonded fixed dental prostheses with different framework designs: a systematic review and meta-analysis. J Dent. 2016;47:1-7.

80. Chen J, Cai H, Ren X, Suo L, Pei X, Wan Q. A systematic review of the survival and complication rates of all-ceramic resin-bonded fixed dental prostheses. J Prosthodont. 2018:27(6):535-43.

81. Dhima M, Carr AB, Salinas TJ, Lohse C, Berglund L, Nan KA. Evaluation of fracture resistance in aqueous environment under dynamic loading of lithium disilicate restorative systems for posterior applications. Part 2. J Prosthodont. 2014;23(5):353-7.

82. Seydler B, Rues S, Muller D, Schmitter M. In vitro fracture load of monolithic lithium disilicate ceramic molar crowns with different wall thicknesses. Clin Oral Investig. 2014;18:1165-71.

83. Sasse M, Krummel A, Klosa K, Kern M. Influence of restoration thickness and dental bonding surface on the fracture resistance of full-coverage occlusal veneers made from lithium disilicate ceramic. Dent Mater. 2015;31(8):907-15

84. Vianna ALSV, Prado CJD, Bicalho AA, Pereira RADS, Neves FDD, Soares CJ. Effect of cavity preparation design and ceramic type on the stress distribution, strain and fracture resistance of CAD/CAM onlays in molars. J Appl Oral Sci. 2018;26:e20180004.

85. von Maltzahn NF, E Meniawy Ol, Breitenbuecher N, Kohorst P, Stiesch M, Eisenburger M. Fracture strength of ceramic posterior occlusal veneers for functional rehabilitation of an abrasive dentition. Int J Prosthodont. 2018; 31(5):451-2.

86. Mobilio N, Fasiol A, Catapano S. Survival rates of lithium disilicate single restorations: a retrospective study. Int J Prosthodont. 2018;31(3):283-6.

87. Politano G, Van Meerbeek B, Peumans M. Nonretentive bonded ceramic partial crowns: concept and simplified protocol for long-lasting dental restorations. J Adhes Dent. 2018;20(6):495-510.

88. Ferrari M, Ferrari Cagidiaco E, Goracci C, Sorrentino R, Zarone F, Grandini S, Joda T. Posterior partial crowns out of lithium disilicate (LS2) with or without posts: a randomized controlled prospective clinical trial with a 3-year follow up. J Dent. 2019;83:12-7.

89. Makarouna M, Ullmann K, Lazarek K, Boening KW. Six-year clinical performance of lithium disilicate fixed partial dentures. Int J Prosthodont. 2011;24:204-6

90. Taskonak B, Sertgöz A. Two-year clinical evaluation of lithia-disilicate-based all-ceramic crowns and fixed partial dentures. Dent Mater. 2006;22:1008-13.

91. Solá-Ruiz MF, Lagos-Flores E, Román-Rodriguez JL, Highsmith Jdel R, FonsFont A, Granell-Ruiz M. Survival rates of a lithium disilicate-based core ceramic for three-unit esthetic fixed partial dentures: a 10-year prospective study. Int J Prosthodont. 2013;26(2):175-80.

92. Teichmann M, Göckler F, Weber V, Yildirim M, Wolfart S, Edelhoff D. Tenyear survival and complication rates of lithium-disilicate (empress 2 ) toothsupported crowns, implant-supported crowns, and fixed dental prostheses. J Dent. 2017;56:65-77.

93. Kern M, Sasse M, Wolfart S. Ten-year outcome of three-unit fixed dental prostheses made from monolithic lithium disilicate ceramic. J Am Dent Assoc. 2012;143:234-40.

94. Abdel-Azim T, Rogers K, Elathamna E, Zandinejad A, Metz M, Morton D. Comparison of the marginal fit of lithium disilicate crowns fabricated with
CAD/CAM technology by using conventional impressions and two intraoral digital scanners. J Prosthet Dent. 2015;114(4):554-9.

95. Zeltner M, Sailer I, Mühlemann S, Özcan M, Hämmerle CH, Benic GI. Randomized controlled within-subject evaluation of digital and conventional workflows for the fabrication of lithium disilicate single crowns. Part III: marginal and internal fit. J Prosthet Dent. 2017;117(3):354-62.

96. Haddadi Y, Bahrami G, Isidor F. Accuracy of crowns based on digital intraoral scanning compared to conventional impression-a split-mouth randomised clinical study. Clin Oral Investig. 2019. https://doi.org/10.1007/ s00784-019-02840-0

97. Anadioti E, Aquilino SA, Gratton DG, Holloway JA, Denry I, Thomas GW, Qian F. 3D and 2D marginal fit of pressed and CAD/CAM lithium disilicate crowns made from digital and conventional impressions. J Prosthodont. 2014;23(8):610-7.

98. Memari Y, Mohajerfar M, Armin A, Kamalian F, Rezayani V, Beyabanaki E. Marginal adaptation of CAD/CAM all-ceramic crowns made by different impression methods: a literature review. J Prosthodont. 2019;28(2):e536-44.

99. Mostafa NZ, Ruse ND, Ford NL, Carvalho RM, Wyatt CCL. Marginal fit of lithium disilicate crowns fabricated using conventional and digital methodology: a three-dimensional analysis. J Prosthodont. 2018;27(2): $145-52$.

100. Ng J, Ruse D, Wyatt C. A comparison of the marginal fit of crowns fabricated with digital and conventional methods. J Prosthet Dent. 2014;112(3):555-60.

101. Alfaro DP, Ruse ND, Carvalho RM, Wyatt CC. Assessment of the internal fit of lithium disilicate crowns using micro-CT. J Prosthodont. 2015;24:381-6.

102. Schaefer O, Decker M, Wittstock F, Kuepper H, Guentsch A. Impact of digital impression techniques on the adaption of ceramic partial crowns in vitro. J Dent. 2014:42(6):677-83.

103. Mously HA, Finkelman M, Zandparsa R, Hirayama H. Marginal and internal adaptation of ceramic crown restorations fabricated with CAD/ CAM technology and the heat-press technique. J Prosthet Dent. 2014; 112:249-56.

104. Guess PC, Vagkopoulou T, Zhang Y, Wolkewitz M, Strub JR. Marginal and internal fit of heat pressed versus CAD/CAM fabricated all-ceramic onlays after exposure to thermo-mechanical fatigue. J Dent. 2014;42(2): 199-209.

105. Azar B, Eckert S, Kunkela J, Ingr T, Mounajjed R. The marginal fit of lithium disilicate crowns: press vs. CAD/CAM. Braz Oral Res. 2018;32:e001.

106. Neves FD, Prado CJ, Prudente MS, Carneiro TA, Zancopé K, Davi LR, Mendonça G, Cooper LF, Soares CJ. Micro-computed tomography evaluation of marginal fit of lithium disilicate crowns fabricated by using chairside CAD/CAM systems or the heat-pressing technique. J Prosthet Dent. 2014;112(5):1134-40.

107. Homsy F, Bottin M, Özcan M, Majzoub Z. Fit accuracy of pressed and milled lithium disilicate inlays fabricated from conventional impressions or a laboratory-based digital workflow. Eur J Prosthodont Restor Dent. 2019; 27(1):18-25.

108. Revilla-León M, Olea-Vielba M, Esteso-Saiz A, Martínez-Klemm I, Özcan M. Marginal and internal gap of handmade, milled and 3D printed additive manufactured patterns for pressed lithium disilicate onlay restorations. Eur J Prosthodont Restor Dent. 2018;26(1):31-8.

109. Elsaka SE, Elnaghy AM. Mechanical properties of zirconia reinforced lithium silicate glass-ceramic. Dent Mater. 2016;32(7):908-14.

110. Sen N, Us YO. Mechanical and optical properties of monolithic CAD-CAM restorative materials. J Prosthet Dent. 2018;119(4):593-9.

111. Lauvahutanon S, Takahashi H, Shiozawa M, Iwasaki N, Asakawa Y, Oki M, Finger WJ, Arksornnukit M. Mechanical properties of composite resin blocks for CAD/ CAM. Dent Mater J. 2014;33(5):705-10.

112. Vichi A, Fonzar RF, Goracci C, Carrabba M, Ferrari M. Effect of finishing and polishing on roughness and gloss of lithium disilicate and lithium silicate zirconia reinforced glass ceramic for CAD/CAM systems. Oper Dent. 2018; 43(1):90-100.

113. Passos L, Linke B, Street A, Torrealba Y. Effect of thickness, translucency, and firing protocol on the masking ability of a CAD/CAM zirconiareinforced lithium silicate for different backgrounds. Int I Comput Dent. 2019;22(1):29-38.

114. Ramos Nde C, Campos TM, Paz IS, Machado JP, Bottino MA, Cesar PF, Melo RM. Microstructure characterization and SCG of newly engineered dental ceramics. Dent Mater. 2016:32(7):870-8.

115. Fathy SM, Swain MV. In-vitro wear of natural tooth surface opposed with zirconia reinforced lithium silicate glass ceramic after accelerated ageing. Dent Mater. 2018;34(3):551-9. 
116. Zimmermann M, Koller C, Mehl A, Hickel R. Indirect zirconia-reinforced lithium silicate ceramic CAD/CAM restorations: preliminary clinical results after 12 months. Quintessence Int. 2017;48(1):19-25.

117. Saavedra GSFA, Rodrigues FP, Bottino MA. Zirconia-reinforced lithium silicate ceramic - a 2-year follow-up of a clinical experience with anterior crowns. Eur J Prosthodont Restor Dent. 2017;25(1):57-63.

118. Denry I, Kelly JR. State of the art of zirconia for dental applications. Dent Mater. 2008;24:299-307.

119. Zarone F, Russo S, Sorrentino R. From porcelain-fused-to-metal to zirconia: clinical and experimental considerations. Dent Mater. 2011;27(1):83-96.

120. Miyazaki T, Nakamura T, Matsumura H, Ban S, Kobayashi T. Current status of zirconia restoration. J Prosthodont Res. 2013;57(4):236-61.

121. Chen YW, Moussi J, Drury JL, Wataha JC. Zirconia in biomedical applications. Expert Rev Med Devices. 2016;13(10):945-63.

122. Zarone F, Sorrentino R, Vaccaro F, Traini T, Russo S, Ferrari M. Acid etching surface treatment of feldspathic, alumina and zirconia ceramics: a micromorphological SEM analysis. Int Dent South Afr. 2006:8:50-6.

123. Nakashima J, Taira Y, Sawase T. In vitro wear of four ceramic materials and human enamel on enamel antagonist. Eur J Oral Sci. 2016;124:295-300.

124. Sorrentino R, Navarra CO, Di Lenarda R, Breschi L, Zarone F, Cadenaro M, Spagnuolo $\mathrm{G}$. Effects of finish line design and fatigue cyclic loading on phase transformation of zirconia dental ceramics: a qualitative micro-Raman spectroscopic analysis. Materials. 2019;12:6. https://doi.org/10.3390/ma12060863.

125. Lughi V, Sergo V. Low temperature degradation -aging- of zirconia: a critical review of the relevant aspects in dentistry. Dent Mater. 2010;26(8):807-20.

126. Camposilvan E, Leone R, Gremillard L, Sorrentino R, Zarone F, Ferrari M, Chevalier J. Aging resistance, mechanical properties and translucency of different yttriastabilized zirconia ceramics for monolithic dental crown applications. Dent Mater. 2018;34(6):879-90.

127. Ferrari M, Vichi A, Zarone F. Zirconia abutments and restorations: from laboratory to clinical investigations. Dent Mater. 2015;31:e63-76.

128. Rodrigues CDS, Aurélio IL, Kaizer MDR, Zhang Y, May LG. Do thermal treatments affect the mechanical behavior of porcelain-veneered zirconia? A systematic review and meta-analysis. Dent Mater. 2019:35(3):807-17.

129. Mota YA, Cotes C, Carvalho RF, Machado JPB, Leite FPP, Souza ROA, Özcan M. Monoclinic phase transformation and mechanical durability of zirconia ceramic after fatigue and autoclave aging. J Biomed Mater Res B Appl Biomater. 2017;105(7):1972-7.

130. Wille S, Zumstrull P, Kaidas V, Jessen LK, Kern M. Low temperature degradation of single layers of multilayered zirconia in comparison to conventional unshaded zirconia: phase transformation and flexural strength. J Mech Behav Biomed Mater. 2018;77:171-5.

131. Sun T, Zhou S, Lai R, Liu R, Ma S, Zhou Z, Longquan S. Load-bearing capacity and the recommended thickness of dental monolithic zirconia single crowns. J Mech Behav Biomed Mater. 2014;35:93-101.

132. Lameira DP, Buarque e Silva WA, Andrade e Silva F, De Souza GM. Fracture strength of aged monolithic and bilayer zirconia-based crowns. Biomed Res Int. 2015;2015:418641.

133. Lan TH, Liu PH, Chou MM, Lee HE. Fracture resistance of monolithic zirconia crowns with different occlusal thicknesses in implant prostheses. J Prosthet Dent. 2016;115(1):76-83.

134. Sorrentino R, Triulzio C, Tricarico MG, Bonadeo G, Gherlone EF, Ferrari M. In vitro analysis of the fracture resistance of CAD-CAM monolithic zirconia molar crowns with different occlusal thickness. J Mech Behav Biomed Mater. 2016;61:328-33.

135. Nakamura $K$, Harada A, Inagaki $R$, Kanno T, Niwano $Y$, Milleding $P$, Örtengren $U$. Fracture resistance of monolithic zirconia molar crowns with reduced thickness. Acta Odontol Scand. 2015;73(8):602-8.

136. Ramos GF, Monteiro EB, Bottino MA, Zhang Y, Marques de Melo R. Failure probability of three designs of zirconia crowns. Int J Periodontics Restorative Dent. 2015;35(6):843-9.

137. Weyhrauch M, Igiel C, Scheller H, Weibrich G, Lehmann KM. Fracture strength of monolithic all-ceramic crowns on titanium implant abutments. Int J Oral Maxillofac Implants. 2016;31(2):304-9.

138. Mitov G, Anastassova-Yoshida Y, Nothdurft FP, von See C, Pospiech P. Influence of the preparation design and artificial aging on the fracture resistance of monolithic zirconia crowns. J Adv Prosthodont. 2016;8(1):30-6.

139. Øilo M, Kvam K, Gjerdet NR. Load at fracture of monolithic and bilayered zirconia crowns with and without a cervical zirconia collar. J Prosthet Dent. 2016;115(5):630-6.

140. Zhang Y, Mai Z, Barani A, Bush M, Lawn B. Fracture-resistant monolithic dental crowns. Dent Mater. 2016;32(3):442-9.
141. Elsayed A, Meyer G, Wille S, Kern M. Influence of the yttrium content on the fracture strength of monolithic zirconia crowns after artificial aging. Quintessence Int. 2019. https://doi.org/10.3290/j.qi.a42097.

142. Vichi A, Sedda M, Fabian Fonzar R, Carrabba M, Ferrari M. Comparison of contrast ratio, translucency parameter, and flexural strength of traditional and "augmented translucency" zirconia for CEREC CAD/CAM system. J Esthet Restor Dent. 2016;28(Suppl 1):S32-9.

143. Shahmiri R, Standard OC, Hart JN, Sorrell CC. Optical properties of zirconia ceramics for esthetic dental restorations: a systematic review. J Prosthet Dent. 2018;119(1):36-46.

144. Bacchi A, Boccardi S, Alessandretti R, Pereira GKR. Substrate masking ability of bilayer and monolithic ceramics used for complete crowns and the effect of association with an opaque resin-based luting agent. J Prosthodont Res. 2019. https://doi.org/10.1016/j.jpor.2019.01.005.

145. Venezia P, Torsello F, Cavalcanti R, D'Amato S. Retrospective analysis of 26 complete-arch implant supported monolithic zirconia prostheses with feldspathic porcelain veneering limited to the facial surface. J Prosthet Dent. 2015;114:506-12

146. Sorrentino R, De Simone G, Tetè S, Russo S, Zarone F. Five-year prospective clinical study of posterior three-unit zirconia-based fixed dental prostheses. Clin Oral Investig. 2012;16(3):977-85.

147. Borelli B, Sorrentino R, Goracci C, Amato M, Zarone F, Ferrari M. Evaluating residual dentin thickness following various mandibular anterior tooth preparations for zirconia full-coverage single crowns: an in vitro analysis. Int J Periodontics Restorative Dent. 2015;35(1):41-7.

148. Ferrari M, Sorrentino R, Cagidiaco C, Goracci C, Vichi A, Gherlone E, Zarone F. Short-term clinical performance of zirconia single crowns with different framework designs: 3-year clinical trial. Am J Dent. 2015;28(4):235-40.

149. Fuzzi M, Tricarico MG, Ferrari Cagidiaco E, et al. Nanoleakage and internal adaptation of zirconia and lithium disilicate single crowns with knife edge preparation. J Oss Periodont Prosthodont. 2017;9:262-74.

150. Vichi A, Sedda M, Bonadeo G, Bosco M, Barbiera A, Tsintsadze N, Carrabba M, Ferrari M. Effect of repeated firings on flexural strength of veneered zirconia. Dent Mater. 2015;31(8):e151-6.

151. Lee B, Oh KC, Haam D, Lee JH, Moon HS. Evaluation of the fit of zirconia copings fabricated by direct and indirect digital scanning procedures. J Prosthet Dent. 2018;120(2):225-31.

152. Pilo R, Folkman M, Arieli A, Levartovsky S. Marginal fit and retention strength of zirconia crowns cemented by self-adhesive resin cements. Oper Dent. 2018;43(2):151-61.

153. Riccitiello F, Amato M, Leone R, Spagnuolo G, Sorrentino R. In vitro evaluation of the marginal fit and internal adaptation of zirconia and lithium disilicate single crowns: micro-CT comparison between different manufacturing procedures. Open Dent J. 2018;12:160-72.

154. Pagniano RP, Seghi RR, Rosenstiel SF, Wang R, Katsube N. The effect of a layer of resin luting agent on the biaxial flexure strength of two all-ceramic systems. J Prosthet Dent. 2005;93(5):459-66.

155. Papia E, Larsson C, du Toit M, Vult von Steyern P. Bonding between oxide ceramics and adhesive cement systems: a systematic review. J Biomed Mater Res B Appl Biomater. 2014;102:395-413.

156. Özcan M, Bernasconi M. Adhesion to zirconia used for dental restorations: a systematic review and meta-analysis. J Adhes Dent. 2015;17(1):7-26.

157. Srikanth R, Kosmac T, Della Bona A, Yin L, Zhang Y. Effects of cementation surface modifications on fracture resistance of zirconia. Dent Mater. 2015;31(4):435-42.

158. Luthra R, Kaur P. An insight into current concepts and techniques in resin bonding to high strength ceramics. Aust Dent J. 2016;61:163-73.

159. Sulaiman TA, Abdulmajeed AA, Shahramian K, Lassila L. Effect of different treatments on the flexural strength of fully versus partially stabilized monolithic zirconia. J Prosthet Dent. 2017;118:216-20.

160. Ebeid K, Wille S, Salah T, Wahsh M, Zohdy M, Kern M. Evaluation of surface treatments of monolithic zirconia in different sintering stages. J Prosthodont Res. 2018;62(2):210-7.

161. Dal Piva AMO, Carvalho RLA, Lima AL, Bottino MA, Melo RM, Valandro LF. Silica coating followed by heat-treatment of MDP-primer for resin bond stability to yttria-stabilized zirconia polycrystals. J Biomed Mater Res B Appl Biomater. 2019;107(1):104-11.

162. Pilo R, Dimitriadi M, Palaghia A, Eliades G. Effect of tribochemical treatments and silane reactivity on resin bonding to zirconia. Dent Mater. 2018;34(2): 306-16. 
163. Schünemann FH, Galárraga-Vinueza ME, Magini R, Fredel M, Silva F, Souza JCM, Zhang Y, Henriques B. Zirconia surface modifications for implant dentistry. Mater Sci Eng C Mater Biol Appl. 2019;98:1294-305.

164. Poggio CE, Ercoli C, Rispoli L, Maiorana C, Esposito M. Metal-free materials for fixed prosthodontic restorations. Cochrane Database Syst Rev. 2017. https://doi.org/10.1002/14651858.CD009606.pub2.

165. Bagegni A, Abou-Ayash S, Rücker G, Algarny A, Att W. The influence of prosthetic material on implant and prosthetic survival of implant-supported fixed complete dentures: a systematic review and meta-analysis. J Prosthodont Res. 2019. https://doi.org/10.1016/j.jpor.2019.02.001.

166. Ciancaglini R, Gherlone EF, Radaelli G. Association between loss of occlusal support and symptoms of functional disturbances of the masticatory system. J Oral Rehabil. 1999;26(3):248-53.

167. Ciancaglini R, Gherlone EF, Radaelli S, Radaelli G. The distribution of occlusal contacts in the intercuspal position and temporomandibular disorder. J Oral Rehabil. 2002;29(11):1082-90.

168. Le M, Papia E, Larsson C. The clinical success of tooth- and implantsupported zirconia-based fixed dental prostheses. A systematic review. J Oral Rehabil. 2015;42(6):467-80

169. Wong CKK, Narvekar U, Petridis H. Prosthodontic complications of metalceramic and all-ceramic, complete-arch fixed implant prostheses with minimum 5 years mean follow-up period. A systematic review and metaanalysis. J Prosthodont. 2019;28(2):e722-35.

170. Ferrari M, Tricarico MG, Cagidiaco MC, Vichi A, Gherlone EF, Zarone F, Sorrentino R. 3-year randomized controlled prospective clinical trial on different CAD-CAM implant abutments. Clin Implant Dent Relat Res. 2016; 18(6):1134-41.

171. Abdulmajeed AA, Donovan TE, Cooper LF, Walter R, Sulaiman TA. Fracture of layered zirconia restorations at 5 years: a dental laboratory survey J Prosthet Dent. 2017;118(3):353-6.

172. Fabbri G, Fradeani M, Dellificorelli G, De Lorenzi M, Zarone F, Sorrentino R. Clinical evaluation of the influence of connection type and restoration height on the reliability of zirconia abutments: a retrospective study on 965 abutments with a mean 6-year follow-up. Int J Periodontics Restorative Dent. 2017:37(1):19-31.

173. Sailer I, Balmer M, Hüsler J, Hämmerle CHF, Känel S, Thoma DS. Comparison of fixed dental prostheses with zirconia and metal frameworks: five-year results of a randomized controlled clinical trial. Int J Prosthodont. 2017;30(5):426-8.

174. Roehling S, Schlegel KA, Woelfler H, Gahlert M. Zirconia compared to titanium dental implants in preclinical studies - a systematic review and meta-analysis. Clin Oral Implants Res. 2019;30(5):365-95.

Ready to submit your research? Choose BMC and benefit from:

- fast, convenient online submission

- thorough peer review by experienced researchers in your field

- rapid publication on acceptance

- support for research data, including large and complex data types

- gold Open Access which fosters wider collaboration and increased citations

- maximum visibility for your research: over $100 \mathrm{M}$ website views per year

At $\mathrm{BMC}$, research is always in progress.

Learn more biomedcentral.com/submissions 